\title{
PENGARUH PERCEIVED ORGANIZATIONAL SUPPORT DAN ORGANIZATIONAL-BASED SELF ESTEEM TERHADAP WORK ENGAGEMENT
}

\author{
Ade Indah Dwitasari, Ilhamuddin, Selly Dian Widyasari \\ adeiindah@yahoo.co.id \\ Program Studi Psikologi Fakultas Ilmu Sosial dan Ilmu Politik \\ Universitas Brawijaya
}

\begin{abstract}
ABSTRAK
Penelitian ini dilakukan untuk mengetahui pengaruh perceived organizational support dan organizational-based self-esteem terhadap work engagement. Subjek penelitian ini adalah seluruh karyawan tetap mulai dari level staf sampai kepala bagian di PT. Pupuk Kaltim sebanyak 327 karyawan. Teknik pengambilan sampel menggunakan cluster sampling. Pengumpulan data menggunakan skala perceived organizational support, skala organizationbased self-esteem, dan skala work engagement. Analisis data yang digunakan yaitu metode regresi berganda dengan uji $\mathrm{F}$ dan uji t. Hasil analisis menunjukkan adanya pengaruh secara bersama-sama perceived organizational support dan organizational-based self esteem terhadap work engagement dengan nilai signifikansi sebesar $0.000(0.000<0.05)$. Hasil analisis lain menunjukkan adanya pengaruh perceived organizational support secara parsial terhadap work engagement dengan nilai signifikansi sebesar $0.002(0.002<0.05)$, dan adanya pengaruh organizational based self-esteem secara parsial terhadap work engagement dengan nilai signifikansi sebesar $0.000(0.000<0.05)$. Ini menunjukkan kedua faktor tersebut mempengaruhi work engagement baik secara bersama-sama maupun parsial. Hasil penelitian dapat memberikan pengetahuan kepada perusahaan untuk meningkatkan work engagement pada karyawan dengan memperhatikan kedua faktor tersebut.
\end{abstract}

Kata Kunci: Work Engagement, Organizational, Perceived, Self Esteem,Support

Sumber daya manusia menjadi aset terpenting bagi perusahaan, sehingga perusahaan perlu mengelolanya secara maksimal agar mampu menunjukkan kinerja unggul. Setiap perusahaan membutuhkan individu yang proaktif dan memiliki komitmen yang tinggi untuk bekerja, sehingga perusahaan mampu bertahan dalam menghadapi persaingan yang semakin kuat (Bakker \& Schaufeli, 2008).

Karyawan dengan kinerja unggul saja tidak cukup dalam menghadapi persaingan, sehingga perusahaan membutuhkan karyawan yang terikat pada pekerjaan (Kurniawati, 2014). Work engagement merupakan sikap dan perilaku karyawan dalam bekerja dengan mengekspresikan dirinya secara total, baik fisik, kognitif, afektif, dan emosional. Terdapat penelitian yang mengkorelasikan antara work engagement dengan pencapaian target perusahaan dan menghasilkan hubungan yang positif. Hal tersebut menjadi salah satu alasan mengapa perusahaan membutuhkan karyawan yang dapat terikat dengan pekerjaan mereka (Kurniawati, 2014).

Menurut Bakker (2011), work engagement merupakan keadaan motivasional yang positif yang mengandung karakteristik vigor, 
dedication, dan absorption. Vigor dikarakteristikkan sebagai level energi dan resiliensi yang tinggi. Dedication dikarakteristikkan sebagai keterlibatan kuat yang ditandai rasa antusias dan rasa bangga. Absorption dikarakteristik-kan dengan berkonsentrasi dan terlibat penuh dalam pekerjaan. Individu yang memiliki rasa keterikatan kerja memiliki dampak seperti rendahnya kecenderungan meninggalkan organisasi sehingga organisasi akan merasa terjamin dengan kehadiran dari pekerja (Bakker \& Leiter, 2010).

Menurut Lockwood (Harry, 2014) terdapat dua faktor yang mempengaruhi work engagement yaitu faktor eksternal dan faktor internal. Sementara menurut Bakker \& Demerouti (2008), faktor yang mempengaruhi work engagement antara lain job demands, job resources, personal resource, dan personality. Adapun faktor eksternal yang digunakan yaitu perceived organizational support (POS) dimana ini merupakan salah satu bentuk dukungan sosial yang termasuk dalam job resources. Faktor internal yang digunakan yaitu organizational-based self esteem (OBSE) yang termasuk dalam personal resources. Penelitian ini mengaitkan kedua faktor yang berbeda dikarenakan asumsi peneliti yang menyatakan bahwa faktor yang dapat mempengaruhi keterikatan kerja tidak hanya berasal dari luar individu tetapi juga dari dalam diri individu.

Perceived organizational support adalah dukungan organisasi yang dirasakan dengan keyakinan secara umum mengenai sejauh mana organisasi menilai kontribusi, memperhatikan kesejahteraan, mendengar keluhan, mempehatikan kehidupan karyawan, dan dapat dipercaya untuk memperlakukan karyawan secara adil (Eisenberger \& Rhoades, 2002).
Terdapat tiga dimensi dalam POS antara lain keadilan, dukungan dari atasan, dan imbalan serta kondisi kerja. Berdasarkan penelitian yang dilakukan oleh Man dan Hadi (2013) menunjukkan dengan adanya keyakinan individu bahwa perusahaan menghargai setiap kontribusi yang diberikan akan membuat individu mau menunjukkan sikap positif saat bekerja. Perceived organizational support ini menciptakan tanggung jawab bagi karyawan untuk peduli terhadap organisasi dan membantu organisasi mencapai tujuannya (Rhoades, Eisenberger \& Armeli, 2001). POS dinilai sebagai jaminan bahwa organisasi akan menyediakan bantuan untuk menyelesaikan suatu pekerjaan secara efektif dan saat menghadapi kondisi yang tidak menyenangkan seperti stres.

Adapun faktor internal dalam penelitian ini yaitu organizational-based self esteem (OBSE). OBSE adalah tingkat keyakinan anggota organisasi bahwa mereka dapat memuaskan kebutuhan mereka dengan berpartisipasi dan mengambil peran dalam suatu organisasi (Pierce, Gardner, Cummings \& Dunham, 1989). Karyawan yang menilai diri mereka sebagai orang yang berarti akan menjadikan tujuan dan nilai organisasi sebagai bagian dari kehidupan mereka. Hal ini akan membuat karyawan mau menetap dalam suatu organisasi tersebut (Fan, 2008). Individu dengan OBSE yang tinggi merupakan individu yang memiliki rasa kecukupan pribadi sebagai anggota organisasi dan kepuasan dari peran organisasi mereka (Pierce, Gardner, Cummings \& Dunham, 1989). Hasil penelitian ini memfokuskan pada validitas dari konstruk mengenai OBSE.

PT. Pupuk Kaltim merupakan salah satu BUMN dengan penghasil urea dan 
amoniak terbesar di Indonesia. Pengamatan yang dilakukan sebelumnya oleh peneliti saat melakukan praktek kerja lapangan di PT. Pupuk Kaltim mengenai tingkatan work engagement, sekitar $51.35 \%$ berada pada kategori rendah dan $0.90 \%$ berada pada kategori sangat rendah (Dwitasari, 2014). Hasil tersebut menunjukkan masih adanya rasa keterikatan kerja karyawan yang rendah baik secara fisik, kognitif, maupun emosional.

Penelitian ini dilakukan untuk mengetahui pengaruh secara bersamasama maupun parsial perceived organizational support dan organizational-based self esteem terhadap work engagement, sehingga diperoleh informasi mengenai besarnya pengaruh secara bersama-sama maupun parsial perceived organizational support dan organizational-based self esteem terhadap work engagement. Hipotesis penelitian ini yaitu adanya pengaruh secara bersamasama maupun parsial perceived organizational support dan organizational-based self esteem terhadap work engagement.

\section{METODE}

Subjek

Subjek penelitian ini sebanyak 327 orang karyawan tetap mulai level staf sampai kepala bagian di PT. Pupuk Kaltim. Teknik sampel dalam penelitian ini menggunakan cluster sampling. Peneliti mengambil 29 departemen dari 54 departemen yang ada untuk menjadi sampel penelitian.

\section{Desain Penelitian}

Penelitian ini menggunakan
penelitian kuantitatif korelasional.
Penelitian ini lebih menekankan pada analisis data numerik sehingga menggunakan penelitian kuantitatif (Azwar, 2014). Selain itu, penelitian ini ingin melihat hubungan antara variabel satu dengan yang lain sehingga peneliti menggunakan penelitian korelasional (Riyanto dalam Zuriah, 2009).

\section{Instrumen Penelitian}

Instrumen penelitian ini menggunakan skala psikologi dan respon jawaban menggunakan model skala likert dengan 4 respon jawaban. Skala yang digunakan dalam penelitian ini terdiri dari tiga skala. Skala perceived organizational support yang mengacu pada teori Eisenberger \& Rhoades (2002) dengan nilai reliabilitas 0.925 Sakala Organizational-based self esteem yang merupakan hasil transadaptasi milik Pierce, Gardner, Cummings, dan Dunham (1989) dengan nilai reliabilitas 0.896. Skala work engagement yang mengacu pada teori Bakker (2011) dengan nilai reliabilitas 0.850 .

\section{Analisis Data}

Analisis data yang digunakan dalam penelitian ini adalah uji asumsi klasik dan uji hipotesis. Uji asumsi klasik terdiri dari uji normalitas, uji multikolinieritas, uji heteroskedastisitas, dan uji autokorelasi. Uji hipotesis dalam penelitian menggunakan analisis regresi berganda dengan uji $F$ dan uji t. 
HASIL

Tabel 1.

Deskripsi Data Variabel Penelitian

\begin{tabular}{cccc}
\hline Variabel & Statistik & $\begin{array}{c}\text { Hipo- } \\
\text { tetik }\end{array}$ & Empirik \\
\hline $\begin{array}{c}\text { Perceived } \\
\text { Organizati } \\
\text { onal }\end{array}$ & $\begin{array}{c}\text { Minimum } \\
\text { Skor }\end{array}$ & 16 & 33 \\
Support & Maksimum & 64 & 64 \\
(POS) & Mean & 40 & 48.16 \\
& SD $(\sigma)$ & 8 & 5.443 \\
& Skor & 10 & 23 \\
Organizati & Minimum \\
on-Based & Skor & 40 & 40 \\
Self Esteem & Maksimum & & \\
(OBSE) & Mean & 25 & 31.31 \\
\multicolumn{5}{c}{ SD $(\sigma)$} & 5 & 3.602 \\
Work & Skor & 11 & 27 \\
Minimum & & \\
Engageme & Skor & 44 & 44 \\
(WE) & Maksimum & & \\
& Mean & 27.5 & 34.68 \\
& SD $(\sigma)$ & 5.5 & 3.668 \\
\hline
\end{tabular}

Berdasarkan kategorisasi penelitian dapat diketahui bahwa pada variabel perceived organizational support, subjek tidak ada yang berada pada kategori rendah. Sebanyak 127 orang (38.8\%) berada pada kategori sedang dan 200 orang $(61.2 \%)$ berada pada kategori tinggi.

Pada variabel organizational-based self esteem, tidak ada subjek yang berada pada kategori rendah. Sebanyak 69 orang (21.1\%) berada pada kategori sedang dan 258 orang $(78.9 \%)$ berada pada kategori tinggi.

Pada variabel work engagement, subjek juga tidak ada yang berada pada kategori rendah. Sebanyak 84 orang (25.7\%) berada pada kategori sedang dan
243 orang $(74.3 \%)$ berada pada kategori tinggi.

Sebelum melakukan uji hipotesis, dilakukan uji asumsi terlebih dahulu. Uji asumsi yang dilakukan yaitu uji normalitas, uji multikolinieritas, uji heteroskedastisitas, dan uji autokorelasi.

Tabel 3.

Uji Normalitas

\begin{tabular}{|c|c|c|}
\hline Variabel & Sig. & Keterangan \\
\hline POS & 0.000 & $\begin{array}{c}\text { Tidak } \\
\text { normal }\end{array}$ \\
\hline OBSE & 0.000 & $\begin{array}{c}\text { Tidak } \\
\text { normal }\end{array}$ \\
\hline WE & 0.000 & $\begin{array}{c}\text { Tidak } \\
\text { normal }\end{array}$ \\
\hline
\end{tabular}

Pada uji normalitas didapat keseluruhan nilai signifikan bernilai 0.000 yang berarti kurang dari 0.05. Hal ini menunjukkan bahwa keseluruhan data tidak terdistribusi secara normal. Hal ini dapat disebabkan karena banyaknya nilai ekstrim atau outliers dalam satu data. Selain itu, hal ini juga bisa terjadi karena banyaknya varians pada subjek penelitian.

Tabel 4.

Hasil uji multikolinieritas

\begin{tabular}{ccc}
\hline $\begin{array}{c}\text { Variabel } \\
\text { Bebas }\end{array}$ & VIF & Keterangan \\
\hline $\mathrm{X}_{1}$ & 1,338 & Non Multikolinier \\
$\mathrm{X}_{2}$ & 1,338 & Non Multikolinier \\
\hline
\end{tabular}

Pada uji multikolinieritas didapat nilai VIF sebesar 1.338 yang berarti nilai tersebut berada di sekitar angka 1 . Hal ini menunjukkan bahwa tidak terjadi masalah multikolinieritas. 


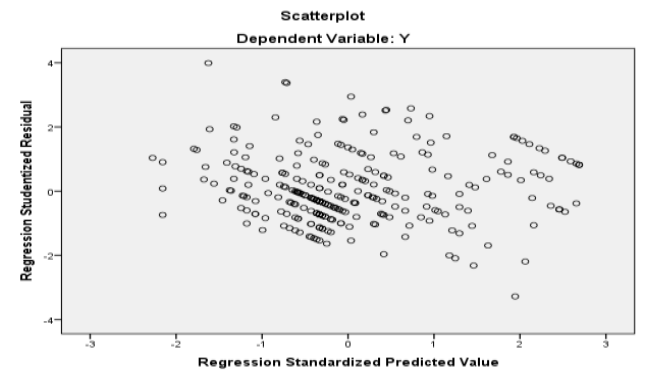

Gambar 1. Uji Heteroskedastisitas

Dari gambar 1. dapat diketahui bahwa tidak ada pola yang jelas dan titik-titik menyebar diatas dan dibawah angka 0 pada sumbu Y. Ini menunjukkan bahwa tidak terjadi heteroskedastisitas.

Tabel 5.

Uji autokorelasi

\begin{tabular}{cc}
\hline Durbin-Watson & Keterangan \\
\hline 1.925 & Tidak ada \\
& autokorelasi \\
\hline
\end{tabular}

Pada uji autokorelasi didapat besaran angka D-W sebesar 1.925. Hasil tersebut menunjukkan bahwa nilai $\mathrm{D}-\mathrm{W}$ berada diantara -2 sampai +2 yang berarti tidak adanya autokorelasi.

Menurut Azwar (2000), uji normalitas tidak perlu dikhawatirkan selama memiliki sampel yang cukup besar. Data dalam jumlah besar biasanya di atas 30 (Santoso, 2014). Uji normalitas ini juga tidak perlu dilakukan karena nilai $\mathrm{F}$ tidak begitu terpengaruh oleh penyimpangan normalitas distribusi.

Hal ini juga didukung oleh pernyataan dalam Field (2009). Beberapa orang masih mengalami kebingungan mengenai asumsi bahwa prediktor yang harus terdistribusi secara normal. Menurutnya, data prediktor tidak harus didistribusikan secara normal. Dari penjelasan tersebut, maka peneliti tetap menggunakan analisis parametrik dengan metode analisis regresi berganda dalam pengujian hipotesis.

Setelah melakukan uji asumsi, selanjutnya melakukan pengujian hipotesis menggunakan analisis regresi berganda dengan uji $\mathrm{F}$ dan uji t.

Tabel 6.

Tabel Analisis Regresi

\begin{tabular}{ccccc}
\hline Model & $\begin{array}{c}\text { Koef. } \\
\boldsymbol{\beta}\end{array}$ & $\mathbf{t}$ & Sig. & $\begin{array}{c}\text { Ket } \\
\text {. }\end{array}$ \\
\hline $\begin{array}{c}\text { (Constant) } \\
\text { Perceived }\end{array}$ & 9.066 & 6.547 & .000 & Sig. \\
$\begin{array}{c}\text { Organizati } \\
\text { on Support } \\
\text { Organizati } \\
\text { on Based } \\
\text { Self }\end{array}$ & .090 & 3.111 & .002 & Sig. \\
Esteem & .680 & 15.537 & .000 & Sig. \\
\hline
\end{tabular}

Dari tabel 6 didapat persamaan regresi sebagai berikut:

$\mathrm{Y}=9.066+0.090 \mathrm{X}_{1}+0.680 \mathrm{X}_{2}$

\section{Keterangan:}

Y : Work engagement

$\mathrm{X}_{1} \quad$ : Percieved Organizational

\section{Support}

$\mathrm{X}_{2} \quad$ : Organizational-Based Self Esteem

Persamaan regresi diatas menunjukkan bahwa apabila $\mathrm{X}_{1}$ mengalami penambahan 1 poin dengan asumsi $\mathrm{X}_{2}$ tetap, maka $\mathrm{Y}$ akan naik sebesar 0.090. Ini menunjukkan bahwa jika perceived organization support meningkat, maka work engagement juga akan meningkat. Selain itu persamaan regresi diatas juga menunjukkan bahwa jika $\mathrm{X}_{2}$ mengalami penambahan 1 poin dengan asumsi $\mathrm{X}_{1}$ tetap, maka nilai $\mathrm{Y}$ akan naik sebesar 0.680. Ini menunjukkan bahwa jika organizational-based self esteem. meningkat, maka work engagement juga akan meningkat. 
Pengujian hipotesis 1 dengan uji $\mathrm{F}$ diperoleh hasil sebagai berikut:

Tabel 7.

Hasil Uji Hipotesis 1

\begin{tabular}{ccccc}
\hline $\begin{array}{c}\mathbf{R} \\
\text { square }\end{array}$ & $\begin{array}{c}\mathbf{F} \\
\text { hitung }\end{array}$ & $\begin{array}{c}\text { F } \\
\text { tabel }\end{array}$ & Sig. & Ket. \\
\hline 0.553 & 200.526 & 3.00 & 0.000 & $\begin{array}{c}\text { Signi } \\
\text { fikan }\end{array}$ \\
\hline
\end{tabular}

Dari tabel 7 dapat diketahui bahwa

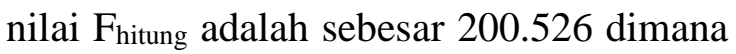
nilai tersebut lebih besar dari nilai $F_{\text {tabel }}$ (200.526 > 3.00), maka dari itu hipotesis 1 diterima. Hasil tersebut menunjukkan bahwa perceived organizational support dan organizational-based self esteem secara bersama-sama mempengaruhi work engagement. Selain itu, dapat diketahui bahwa pengaruh perceived organizational support dan organizational-based self esteem terhadap work engagement sebesar $55.3 \%$.

Pengujian hipotesis 2 dan 3 dengan uji t diperoleh hasil sebagai berikut:

Tabel 8.

Hasil Uji Hipotesis 2

\begin{tabular}{lccc}
\hline $\mathbf{t}_{\text {hitung }}$ & $\mathbf{t}_{\text {tabel }}$ & Sig. & Ket. \\
\hline 3.111 & 1.960 & 0.002 & Signifikan \\
\hline
\end{tabular}

Dari tabel 8 dapat dilihat bahwa

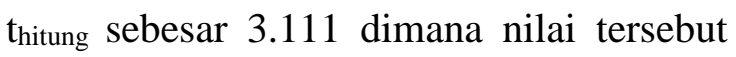
lebih besar dari nilai tabel $(3.111>1.960)$, maka dari itu hipotesis 2 diterima. Hasil tersebut dapat dikatakan bahwa perceived organization support secara parsial mempengaruhi work engagement.

Tabel 9.

Hasil Uji Hipotesis 3

\begin{tabular}{cccc}
\hline $\mathbf{t}_{\text {hitung }}$ & $\mathbf{t}_{\text {tabel }}$ & Sig. & Ket. \\
\hline 15.537 & 1.960 & 0.000 & Signifikan \\
\hline
\end{tabular}


Adanya dukungan dari organisasi yang dirasakan akan membuat karyawan semakin mampu mengurangi tekanan dalam tuntutan pekerjaan, sehingga akan membuat karyawan mampu mengekspresikan dirinya saat bekerja. Organizational-based self esteem merupakan tipikal dari personal resources. Karyawan yang menilai diri mereka sebagai individu yang penting dan berharga akan membuat karyawan merasa organisasi menyatu dalam kehidupannya. Hal ini akan membuat karyawan untuk tetap tinggal dan bergabung dengan perusahaan (Indrayanto \& Nugroho, 2013).

Dalam penelitian ini, sebanyak 200 orang (61.2\%) memiliki nilai yang cenderung tinggi pada aspek perceived organizational support dan sekitar 258 orang $(78.9 \%)$ memiliki nilai organizational-based self esteem yang cenderung tinggi. Nilai tersebut menunjukkan bahwa banyaknya subjek yang merasakan adanya dukungan yang diberikan oleh perusahaan dan memiliki keyakinan bahwa mereka dapat memuaskan kebutuhan mereka dengan berpartisipasi dalam suatu organisasi. Adanya pujian yang diberikan atasan kepada bawahan sebagai salah satu bentuk dari dukungan atasan dan anggapan karyawan bahwa mereka memiliki keyakinan mampu melakukan suatu pekerjaan dengan baik, membuat karyawan akan bekerja secara maksimal untuk terus mendapatkan hasil yang terbaik. Karyawan yang merasa bahwa atasan memperhatikan setiap permasalahan yang dihadapi dan merasa mampu bekerjasama baik dengan atasan maupun rekan kerja, akan membuat karyawan mau berperan secara aktif dalam suatu pekerjaan (Bakker, Albrect \& Leiter, 2011).
Pemberian feedback dan pemberian berbagai macam keterampilan yang diberikan oleh perusahaan secara positif berkaitan dengan work engagement karyawan (Bakker \& Demerouti, 2008). Hal ini menunjukkan karyawan yang menganggap perusahaan memperhatikan setiap kemampuan dirinya dan merasa diri mereka merupakan individu yang penting didalam perusahaan, akan membuat karyawan akan menunjukkan performa terbaiknya. Adanya anggapan karyawan bahwa perusahaan memberikan jaminan karir masa depan yang baik dan merasa diri mereka berharga dalam perusahaan, akan membuat karyawan merasa bangga bisa bekerja di perusahaan tersebut serta merasakan hubungan yang mendalam dengan pekerjaannya (Bakker, Albrect \& Leiter, 2011).

Hipotesis kedua mengenai pengaruh perceived organizational support terhadap work engagement menunjukkan nilai thitung lebih besar dari $t_{\text {tabel }}(3.111>1.960)$. Hal ini menunjukkan bahwa adanya pengaruh secara parsial perceived organizational support terhadap work engagement. Dimana semakin karyawan merasakan adanya dukungan yang diberikan oleh perusahaan akan membuat karyawan semakin terikat dengan pekerjaan mereka. Hasil ini sesuai dengan penelitian yang dilakukan oleh Man dan Hadi (2013), dimana dengan adanya dukungan yang diberikan oleh organisasi yang diwujudkan sebagai bentuk investasi sumber daya manusia akan meningkatkan rasa keterikatan kerja guru serta berdampak pada perilaku positif guru.

Adanya keyakinan pada karyawan bahwa organisasi memberikan dukungan penuh terhadap kesejahteraan mereka, membuat karyawan akan memberikan performa terbaiknya dan membuat mereka 
merasa terikat dengan pekerjaan mereka (Bakker, Albrect \& Leiter, 2011). Hal ini menunjukkan semakin organisasi mampu membuat karyawan merasa adanya dukungan yang diberikan oleh organisasi kepada mereka maka akan membuat karyawan semakin mampu mengekspresikan diri mereka baik secara fisik, kognitif, maupun emosional saat bekerja. Organisasi yang memberikan dukungan kepada karyawan dengan memperlakukan mereka secara hormat dan bermartabat, diharapkan akan membuat karyawan memberikan kinerja terbaiknya. Menurut Gouldner (Putra, 2013), setelah karyawan merasakan adanya perlakuan tersebut, karyawan merasa penting untuk membalasnya. Hal ini akan membuat karyawan secara tidak langsung merasa terikat dengan pekerjaan mereka, dimana karyawan perlu memberikan kinerja terbaik pada pekerjaan mereka.

Perusahaan memberikan imbalan sesuai seperti kesempatan untuk dipromosikan kepada karyawan yang berkinerja unggul, akan membuat karyawan memiliki semangat yang tinggi dan bersungguh-sungguh dalam bekerja. Selain itu dengan perusahaan mendengarkan setiap kritik dan saran yang diberikan oleh karyawan akan membuat karyawan selalu berusaha mengabdikan diri mereka di perusahaan dengan memunculkan ide-ide terbaru untuk kemajuan pengembangan perusahaan. Perusahaan senantiasa memperhatikan setiap masukan dari karyawan akan membuat karyawan merasa lebih dihargai dan karyawan akan semakin memahami kontribusi pekerjaan mereka pada tujuan yang lebih besar (Kurniawati, 2014).

Hipotesis ketiga mengenai pengaruh organizational-based self esteem terhadap work engagement didapat nilai thitung lebih besar dari $\mathrm{t}_{\text {tabel }}(15.537>1.960)$. Hasil tersebut menunjukkan bahwa adanya pengaruh secara parsial organizationalbased self esteem terhadap work engagement. Semakin karyawan memiliki keyakinan bahwa dengan perannya dalam suatu organisasi membuat dirinya mampu memenuhi kebutuhannya, membuat karyawan akan semakin terikat dengan pekerjaan mereka.

Hal ini sesuai dengan yang diungkapkan oleh Demerouti (Puspita, 2012) dimana organizational-based self esteem merupakan salah satu hal yang termasuk kedalam personal resources. Personal resources termasuk kedalam salah satu faktor yang mempengaruhi work engagement. Hasil penelitian ini juga sejalan dengan penelitian yang dilakukan oleh Indrayanto dan Nugroho (2013) dimana OBSE merupakan variabel yang dapat dijadikan sarana bagi perusahaan dalam meningkatkan komitmen karyawan. OBSE dapat ditingkatkan dengan memperhatikan pelaksanaan pelatihan yang bertujuan mengembangkan sikap dan perasaan dari karyawan karena telah menjadi bagian dari perusahaan.

Hasil penelitian ini menunjukkan bahwa karyawan yang merasa bahwa diri mereka memiliki keyakinan didalam diri mereka dan merasa bahwa mereka diperhitungkan ditempat kerja akan membuat karyawan tidak berputus asa dalam menyelesaikan pekerjaan yang tidak begitu dipahami serta akan bekerja secara maksimal. Hal ini secara tidak langsung akan membuat karyawan terikat dengan pekerjaannya (Kurniawati, 2014). Selain itu karyawan yang merasa bahwa dirinya dapat membuat suatu perbedaan yang positif akan membuat mereka semakin tertantang untuk mengerjakan pekerjaan yang belum pernah dikerjakan sebelumnya 
Pengaruh Perceived Organizational Support dan Organizational-Based Self Esteem terhadap Work Engagement

dan terlibat secara penuh terhadap pekerjaan mereka (Mujiasih \& Ratnaningsih, 2012).

Menurut Bakker dan Demerouti (2008), karyawan yang menganggap bahwa diri mereka dapat dipercaya baik oleh atasan maupun rekan kerja akan membuat karyawan aktif berpartisipasi menjadi bagian dari suatu organisasi dan bergabung dalam menyelesaikan suatu permasalahan dalam pekerjaan. Menurut Khan (Mujiasih \& Ratnaningsih, 2012) karyawan yang merasa bahwa dirinya merupakan individu yang penting dalam suatu organisasi akan membuat diri mereka merasa semakin terikat secara fisik, kognitif, maupun emosional terhadap pekerjaan. Salah satu saran penelitian yang dapat diberikan yaitu memberikan lebih banyak penghargaan kepada karyawan teladan dalam setiap unit kompartemen agar wujud pengakuan kontribusi dalam setiap kompartemen lebih terlihat. Hasil penelitian ini dapat memberikan pengetahuan untuk perusahaan untuk dapat meningkatkan work engagement karyawan dengan memperhatikan kedua faktor yaitu perceived organizational support dan organizational-based self esteem.

\section{KESIMPULAN}

Berdasarkan hasil penelitian diatas, dapat diambil kesimpulan bahwa perceived organizational support dan organizational-based self esteem secara bersama-sama mempengaruhi work engagement. Selain itu, terdapat pengaruh secara parsial perceived organizational support terhadap work engagement dan organizational-based self esteem terhadap work engagement.

\section{DAFTAR PUSTAKA}

Akbar, M. R. (2013). Pengaruh Budaya Organisasi terhadap Employee Engagement (Studi Pada Karyawan PT. Primatexco Indonesia di Batang). Jurnal Psikologi Sosial dan Industri, Vol. 2 No. 1.

Azwar, S. (2014). Metode Penelitian. Yogyakarta : Pustaka Pelajar.

Azwar, S. (2000). Asumsi-asumsi Inferensi Statistika. Artikel. http://azwar.staff.ugm.ac.id/files/201 0/04/Asumsi-asumsi-dalamInferensi-Statistika1.pdf. diunduh tanggal 7 Agustus 2015.

Bakker, A. B. (2011). An Evidance-Based Model of Work Engagement. Current Directions in Psychological Science, 20 (4) 265-269.

Bakker, A. B., \& Demerouti, E. (2008). Towards a Model of Work Engagement. Career Developmental International, Vol. 13 No. 3, 20922.

Bakker, A. B., \& Schaufeli, W. B. (2008). Positive Organizational Behavior : Engaged employees in Flourishing Organizations. Journal of Organizational Behavior, 29, 147154

Bakker, A.B., \& Leiter, M.P. (2010). Work Engagement: A handbook of essential theory and research (in Japanese). Tokyo : Seiwa-Shoten.

Bakker, A. B., Albrect, S. L., \& Leiter, M. P. (2011). Key Question Regarding Work Engagement. European Journal of Work and Organizational Psychology, 20, 4-28. 
Dwitasari, A. I. (2014). Hubungan antara Perilaku Budaya Kerja dengan Work Engagement Karyawan PT. Pupuk Kalimantan Timur. Praktek Kerja Nyata. (tidak diterbitkan). Malang : Fakultas Ilmu Sosial dan Ilmu Politik.

Eisenberger, R., \& Rhoades, L. (2002). Perceived Organizational Support : A Review of the Literature. Journal of Applied Psychology, Vol. 87 No. 4, 698-714.

Fan, T. L. (2008). The Mediating Role of Organizational-Based Self-Esteem in Training-Commitment Relationship. Diterbitkan oleh Hong kong Baptist University.

Field, A. (2009). Discovering Statistics Using SPSS Third Edition. Sage Publications Asia-Pasicif Pte Ltd : Singapore.

Harry, A. M. (2014). Pengaruh Kompensasi, Status/Pengakuan, dan Kesempatan Berkembang terhadap Tingkat Employee Engagement pada Karyawan Universitas Sanata Dharma. Thesis Manajemen. Yogyakarta : Universitas Atmajaya.

Indrayanto, A., \& Nugroho, S. W. D. (2013). Pengaruh Pelatihan terhadap Komitmen Organisasional dengan Organizational Based Self-Esteem sebagai Variabel Pemediasi. Jurnal Ekonomi, Vol. 18 No. 2

Kurniawati, I. D. (2014). Masa Kerja dengan Job Engagement pada Karyawan. Jurnal Ilmiah Psikologi Terapan, Vol. 2 No. 2.

Man, G. S., \& Hadi, C. (2013). Hubungan antara Perceived Organizational Support dengan Work Engagement pada Guru SMA Swasta di Surabaya.
Jurnal Psikologi Industri dan Organisasi, Vol. 2 No. 2.

Mujiasih, E., \& Ratnaningsih, I. Z. (2012). Meningkatkan Work Engagement melalui Gaya Kepemimpinan Transformasional dan Budaya Organisasi. Jurnal Psikologi.

Pierce, J. L., Gardner, D. G., Cummings, L. L., \& Dunham, R. B. (1989). Organization-Based Self-Esteem: Construct Definition, Measurement, and Validation. Academy of Management Journal, Vol 32 No. 3, 622-648.

Puspita, M. (2012). Hubungan antara Dukungan Sosial dan Makna Kerja sebagai Panggilan (Calling) dengan Keterikatan Kerja. Jurnal Ilmiah Mahasiswa Universitas Surabaya, Vol. 1 No. 1.

Putra, D. (2013). Hubungan antara Perceived Organizational Support dengan Organizational Citizenship Behavior pada Karyawan PT En Seval Putera Megatrading Divisi Transportasi Cabang Sidoarjo. Jurnal Psikologi Industri dan Organisasi, Vol. 2 No. 1.

Rhoades, L., Eisenberger R., \& Armeli, S. (2001). Affective Commitment to the Organization: The Contribution of Perceived Organizational Support. Journal of Applied Psychology, Vol. 86 No. 5 825-836.

Santoso, S. (2014). Statistik Parametrik: Konsep dan Aplikasi dengan SPSS Edisi Revisi. Jakarta : PT Elex Media Komputindo.

Setiawan, I. A. (2012). Hubungan antara Perceived Organizational Support, Job Engagement, dan Task Performance dengan Organizational Citizenship Behavior. Jurnal Sains 
Manajemen \& Akuntansi, Vol.4 No.2.

Waileruny, H. T. (2014). Perceived Organizational Support, Job Satisfaction, dan Organizational Citizenship Behavior Pada PT. Bank Maluku Cabang Utama Kota Ambon. AGORA, Vol. 2 No. 2.

Yungsiana, I. (2013). Pengaruh Psychological Capital dan Organizational-Based Self Esteem terhadap Work Engagement. Skripsi. (tidak diterbitkan) Psikologi Universitas Brawijaya.

Zuriah, N. (2009). Metodologi Penelitian Sosial dan Pendidikan. Jakarta :

Bumi Aksara. 